\title{
Suitability of the predatory mites Iphiseiodes zuluagai and Euseius concordis in controlling Polyphagotarsonemus latus and Tetranychus bastosi on Jatropha curcas plants in Brazil
}

\author{
Renato Almeida Sarmento • Diego Macedo Rodrigues • Farid Faraji • \\ Eduardo A. L. Erasmo • Felipe Lemos • Adenir V. Teodoro • \\ Wagner Toshihiro Kikuchi • Gil Rodrigues dos Santos • Angelo Pallini
}

Received: 20 February 2010/ Accepted: 21 August 2010/Published online: 17 September 2010

(C) The Author(s) 2010. This article is published with open access at Springerlink.com

\begin{abstract}
One of the most promising plant species for biofuel production in Brazil is the physic nut Jatropha curcas. Major phytosanitary problems include the attack of two pest mite species, the broad mite Polyphagotarsonemus latus and the spider mite Tetranychus bastosi. Owing to pesticide-related problems, there is an increasing demand for sustainable environmental-friendly control methods such as biological control. In this study we evaluated the suitability of the predatory mite species Iphiseiodes zuluagai and Euseius concordis in controlling P. latus and T. bastosi on J. curcas. The number of T. bastosi killed by $I$. zuluagai was lower than the number of $P$. latus consumed. Euseius concordis preyed upon both $T$. bastosi and $P$. latus but the number of prey killed was always lower in comparison with I. zuluagai. However, P. latus and T. bastosi are suitable for the development of I. zuluagai and E. concordis as oviposition of both predators did not differ in relation to prey species. The preference of I. zuluagai for leaves of plants infested by either $P$. latus or $T$. bastosi, combined with the higher values for predation obtained by this predatory mite when fed on P. latus, compared to those values obtained by $E$. concordis, suggests that $I$. zuluagai can be more efficient than $E$. concordis in reducing populations of $P$. latus and $T$. bastosi under field conditions. Furthermore, we report here on the first record of predatory mites associated with P. latus and T. bastosi on native J. curcas plants
\end{abstract}

\footnotetext{
R. A. Sarmento $(\bowtie)$ - D. M. Rodrigues · E. A. L. Erasmo - W. T. Kikuchi · G. R. dos Santos Graduate Programme in Plant Science, Federal University of Tocantins (UFT),

PO BOX 66, Gurupi, TO, Brazil

e-mail: rsarmento@uft.edu.br

F. Faraji

University of Amsterdam-Mitox Consultants, Science Park 406, 1098 XH Amsterdam,

The Netherlands
}

F. Lemos - A. Pallini

Department of Animal Biology, Section Entomology, Federal University of Viçosa, Viçosa, Brazil

A. V. Teodoro

Graduate Programme in Agroecology, Maranhão State University (UEMA),

PO BOX 3004, São Luís, MA, Brazil 
in Brazil. In conclusion, we emphasize the crucial importance of predatory mites as agents of natural biological control of mite pests on $J$. curcas in small farms.

Keywords Biological control $\cdot$ Spider mites $\cdot$ Biofuel $\cdot$ Smallholders

\section{Introduction}

The physic nut (Jatropha curcas) is native to equatorial America, where it is traditionally used for hedges, green manure, land reclaim, prevention of erosion and in traditional medicine, and more recently, for biofuel (Gubitz et al. 1999; Openshaw 2000; Fairless 2007; Nature editorial 2007; Kumar and Sharma 2008). In north Brazil, J. curcas is becoming an increasingly popular plant due to its value in the biodiesel industry. Nowadays, 40,000 ha in Brazil are planted with J. curcas, and the area is still expanding. Although the plant can be cultivated on degraded land, and thus does not compete for space with crops, farmers that produce $J$. curcas predominantly use management practices that include high inputs of pesticides and chemical fertilizers. Recently, however, smallholders in Brazil have started to cultivate $J$. curcas as a cash crop, selling the seeds for biodiesel production.

The main phytosanitary problems in cultivating $J$. curcas are the attack of pest mites such as the broad mite Polyphagotarsonemus latus (Banks) (Acari: Tarsonemidae) and the red spider mite Tetranychus bastosi Tuttle, Baker \& Sales (Acari: Tetranychidae) (Lopes 2009; Santos et al. 2006; Kavitha et al. 2007). The broad mite is a highly polyphagous pest attacking several crops worldwide (Gerson 1992; Peña and Bullock 1994; De Moraes and Flechtmann 2008). This minute mite $(0.1-0.3 \mathrm{~mm}$ in length) is found in the apical portion of plants, especially in shoot structures (De Moraes and Flechtmann 2008). This pest causes terminal leaves and flower buds to become malformed, and its attack may occur concomitantly with infestations of $T$. bastosi. The spider mite $T$. bastosi ( $0.5 \mathrm{~mm}$ in length) was first recorded attacking native Jatropha gossypypifolia plants in the northeastern Brazil (Tuttle et al. 1977). The mite was also found infesting weeds, such as Amaranthus viridis L., Bidens pilosa, Ipomoea sp., and Hyptis suaveolens, as well as on crops such as Manihot esculenta and Morus nigra (Tuttle et al. 1977; de Moraes and Delalibera 1992; Bolland et al. 1998). Contrary to $P$. latus, spider mites such as $T$. bastosi have a silk spinning behavior, covering their colonies with webbing, which may difficult predatory mites to penetrate on their colonies (Saito 1985; Gerson 1985; Sabelis and Bakker 1992). They are more frequently found on underside of fully-developed leaves of J. curcas in comparison with younger leaves.

In Brazil, chemical control is the main method of combating pest mites (Oliveira et al. 2007). Due to excessive use of pesticides and the associated problems of pesticide resistance and environmental pollution, there is an increasing demand for sustainable environmentalfriendly control methods. Biological control of pest mites is viewed as an alternative method to chemical control. Predatory mites of the family Phytoseiidae are key natural enemies of pest mites (McMurtry and Croft 1997; De Moraes et al. 2004) and the biological control provided by such indigenous species is considered an environmental service to smallholders which normally lack the resources to control pest mites in their fields. The predatory mites Iphiseiodes zuluagai Denmark \& Muma and Euseius concordis Chant (Acari: Phytoseiidae) are the most common natural enemies associated with P. latus and T. bastosi on J. curcas plants in the region where the study was conducted (Rodrigues et al. in prep). Predatory mites forage for prey guided by volatiles that are produced by plants in response to herbivore injury (Dicke and Sabelis 1988; Dicke 1994; Turlings et al. 1990; Janssen et al. 1999; 
Sabelis et al. 2001), and therefore, the ability of these predators to find prey infested plants is key in order to biological control to succeed (Oliveira et al. 2009).

Here, we evaluated the potential of biological control of the predatory mites I. zuluagai and E. concordis on the phytophagous mites $P$. latus and T. bastosi. We investigated the suitability of $P$. latus and $T$. bastosi as prey for $I$. zuluagai and $E$. concordis using predation bioassays and the oviposition rate experiments as a fitness measure. Another important trait to be considered when selecting a predator for biological control purposes is its ability to find prey-infested plants (Oliveira et al. 2009), therefore, we assessed the attraction of both predatory mites to leaves of plants infested with P. latus or $T$. bastosi through releaserecapture experiments.

\section{Materials and methods}

\section{Plant material and mite rearing}

Seedlings $(15 \mathrm{~cm})$ of $J$. curcas were transplanted into individual plastic pots $(500 \mathrm{ml})$ containing soil and manure in a 3:1 portion. Stock cultures of both I. zuluagai and E. concordis were started with mites collected on J. curcas plants. Stock colonies were established on arenas prepared with 6-cm diameter flexible plastic discs floating on distilled water. Castor bean pollen (Ricinus communis L.) was added on a daily-basis as food for the mites (Reis and Alves 1997). Stock colonies of P. latus and T. bastosi were started with mites collected from infested native J. curcas plants, which were subsequently transferred to uninfested plants. Both, predatory and spider mites were maintained inside a climate chamber $\left(28{ }^{\circ} \mathrm{C}, 65-70 \%\right.$ R.H. and $12 \mathrm{~h} \mathrm{~L} / 12 \mathrm{~h}$ D photoperiod). Each experiment was carried out in separated chambers at the laboratory of Entomology of the Federal University of Tocantins, Gurupi, Tocantins, Brazil.

\section{Predation rate relative to prey density}

The predatory activity of I. zuluagai and E. concordis on P. latus and T. bastosi was evaluated on leaf discs $(\varnothing=3 \mathrm{~cm})$ made from healthy and unsprayed $J$. curcas plants. Discs were kept in batches of 10 in plastic trays $(30 \times 20 \mathrm{~cm})$ containing foam covered with wet cotton wool and soaked with water to prevent mites from escaping. The trays were kept inside a climate chamber at the same conditions described above. Leaf discs were infested with 2-day-old mated females of each pest mite species ( $P$. latus or T. bastosi), according to each treatment on the following prey densities: $5,10,15$ and 20 individuals per disc. Predators were starved in the presence of water for $2 \mathrm{~h}$ before used in the experiments. Subsequently, one young mated female of each predatory mite species (I. zuluagai or E. concordis) was released on each disc according to each treatment. After $8 \mathrm{~h}$, the predation rate of each predatory mite was calculated by counting the number of mites preyed per disc. Each treatment consisted of 20 replicates.

\section{Predatory mite oviposition}

To evaluate the oviposition rate of I. zuluagai and E. concordis on P. latus or T. bastosi one 2-day-old female plus one male of each predatory species were confined on leaf discs $(\varnothing=5 \mathrm{~cm})$ made from healthy and unsprayed J. curcas plants, infested with P. latus or 
T. bastosi, according to each treatment. The discs with all developmental phases (eggs, larvae, nymphs and adults) ad libitum were kept in plastic trays $(30 \times 20 \times 8 \mathrm{~cm})$ containing foam covered with wet cotton wool and soaked with water to maintain the swelling of the disc and to prevent mites from escaping. The trays were kept inside a climate chamber. Eggs of each predatory mite were quantified and discarded daily for 5 days (Rosa et al. 2005).

\section{Release-recapture experiments}

Release-recapture experiments were conducted to test the attractiveness of the predatory mites I. zuluagai and E. concordis to leaves infested with P. latus and/or T. bastosi (Pallini et al. 1997). Infested leaves were obtained by placing clean (uninfested) plants in contact with mite-infested plants for 1 week. Plants were subsequently removed and the number of mites was estimated. The number of mobile stages on each leaf ranged from 50 to 100. Six young leaves of J. curcas plants of similar age and size (circa length $=3 \mathrm{~cm}$; width $=2 \mathrm{~cm}$ ) were removed from the plants (being three from infested plants and three from control plants) and placed in a circle $(\varnothing=20 \mathrm{~cm})$ spiked on needles that were fixed in a plastic tray $(30 \times 20 \times 8 \mathrm{~cm})$ with silicon glue. In each experiment, uninfested and infested leaves were alternated, so that each uninfested leaf had two infested neighbors, and vice versa. To prevent the predatory mites from escaping a sticky glue (Cola Entomológica, Bio Controle, São Paulo, Brazil) was applied around the circle. Then, 25 females of each predatory mite species (I. zuluagai or E. concordis) were placed in a Petri dish $(\varnothing=2 \mathrm{~cm})$, which was placed inside a larger Petri dish filled with wet cotton wool. Predatory mites were starved for $2 \mathrm{~h}$ before experiments. Subsequently, the Petri dish containing the predatory mites was positioned in the centre of the circle of leaves, and the predators were allowed to access each treatment. Starting $1 \mathrm{~h}$ after release, the leaves were checked for predatory mites every hour for a period of $7 \mathrm{~h}$, and all predatory mites found were removed. All trays were kept in a climate chamber $\left(27 \pm 2{ }^{\circ} \mathrm{C}\right.$, R.H. $\left.75 \pm 10 \%\right)$ during the $7 \mathrm{~h}$ of the evaluation along the day. Each treatment was replicated four times.

\section{Statistical analysis}

Predation rate of I. zuluagai and E. concordis in relation to prey density was analyzed using Generalized Linear Models (GLM) with Poisson error distribution. The difference in the number of mites preyed between predator species, prey species and prey density was compared with a full model. The contrasts between the levels within the model were assessed with Wald test (Kuhn et al. 2008). Oviposition of predatory mites was analyzed using a Generalized Linear Mixed Model (LMER) with Poisson error distribution, with time as random factor to correct for pseudoreplication due to repeated measures (Crawley 2007). Oviposition rates of predatory mites were compared with models consisting of the number of eggs laid in function of predator species and prey species as fixed effects. To analyze differences in numbers of predatory mites recaptured on each of the odour sources (pest mite infested leaves vs. uninfested leaves) we used a $\chi^{2}$ test (expected probability of 0.5 for each treatment). All analyses were performed using the statistical software $\mathrm{R}$ (R Development Core Team 2006). 


\section{Results}

Predation rate relative to prey density

The predation rate of I. zuluagai was higher on P. latus than on T. bastosi in all evaluated densities (Table 1; Fig. 1). There was no significant difference on the predation rate of E. concordis either upon T. bastosi or P. latus in any of the evaluated densities (Table 1; Fig. 2). The predation rate of E. concordis was almost always lower than that of $I$. zuluagai to both prey (Tables 1, 2; Figs. 1, 2).

\section{Predatory mite oviposition}

The oviposition rate of $E$. concordis did not differ between prey species $\left(\chi^{2}=1.0089\right.$, $d f=1, P=0.3152)$. Furthermore, prey species did not affect the oviposition rate of I. zuluagai $\left(\chi^{2}=0.1766, d f=1, P=0.6744\right)$. The predatory mites $E$. concordis and I. zuluagai laid in average $0.9 \pm 0.24$ and $0.9 \pm 0.22$ eggs per day when fed on T. bastosi while they produced in average $0.68 \pm 0.25$ and $1.00 \pm 0.28$ eggs per day when fed on $P$. latus, respectively. Considering the same prey species there is no difference on oviposition rate between predatory mites $\left(\chi^{2}=4.1 \times 10^{-10}, d f=1, P=1\right.$ and $\chi^{2}=1.5332$, $d f=1, P=0.2156$, respectively for $T$. bastosi and $P$. latus $)$.

\section{Release-recapture experiments}

When we assessed the preference of E. concordis to odours of leaves infested with P. latus or uninfested leaves, $87 \%$ of all mites were recaptured from any of the leaves offered as choice to E. concordis. Infested leaves attracted on average $46 \%$ and uninfested leaves attracted $54 \%$ of the recaptured mites (Fig. 4A). When we tested the preference of E. concordis to odours emanating from leaves infested with $T$. bastosi or uninfested ones, $68 \%$ of the mites were recaptured from the leaves (Fig. 4B). On average, $52 \%$ of the mites were found on leaves infested with T. bastosi while uninfested leaves attracted $48 \%$ of the recaptured mites. These results represent no statistical preference of $E$. concordis for uninfested leaves or leaves infested with P. latus or T. bastosi $(P>0.05)$.

When the same options were given to I. zuluagai, the percentage of recaptured mites was also high. When it was offered a choice towards odours of leaves infested with P. latus versus uninfested leaves, $89 \%$ of all I. zuluagai released were recaptured from the leaves. From these recaptured mites, $67 \%$ were attracted to infested leaves while uninfested leaves attracted 33\% mites (Fig. 4C). These difference was significant $(P<0.05)$. When offered a choice to $I$. zuluagai between odours from leaves infested with T. bastosi or uninfested ones, $84 \%$ were recaptured from the leaves. Leaves infested with T. bastosi attracted on average $71 \%$, while uninfested leaves attracted only $29 \%$ of the recaptured mites (Fig. 4D) and this difference was statistically significantly $(P<0.05)$.

\section{Discussion}

Our results indicate that the predatory mites I. zuluagai and E. concordis may contribute to the biological control of the pest mites P. latus and T. bastosi on J. curcas plantations in north Brazil. The number of $P$. latus killed by $I$. zuluagai reached a maximum around 4 


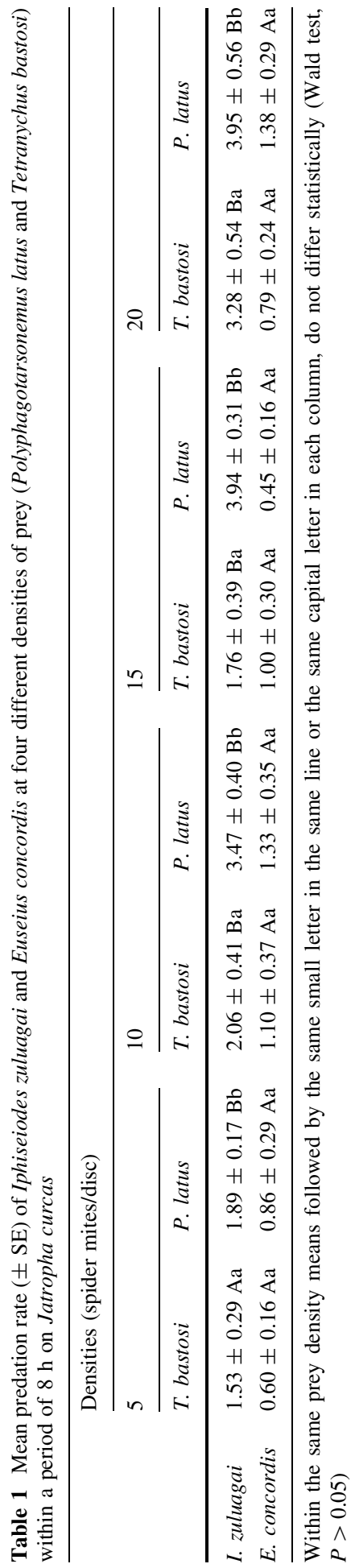


Fig. 1 Mean predation ( \pm SE) of Iphiseiodes zuluagai preying upon different densities of Polyphagotarsonemus latus (solid lines) and Tetranychus bastosi (dotted lines). Different letters denote significant differences among treatments

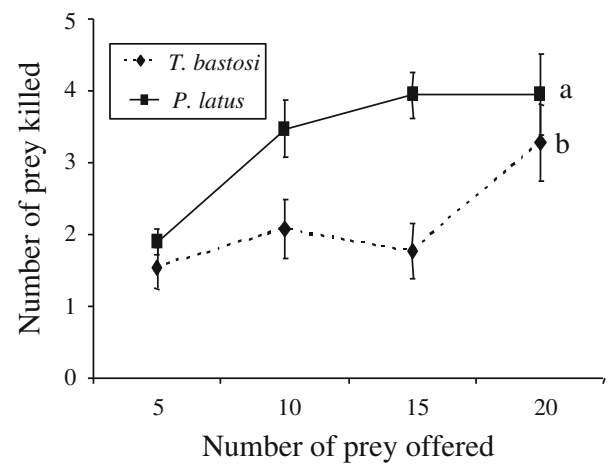

Fig. 2 Mean predation ( \pm SE) of Euseius concordis preying upon different densities of Polyphagotarsonemus latus (solid lines) and Tetranychus bastosi (dotted lines). Same letters denote non-significant differences among treatments

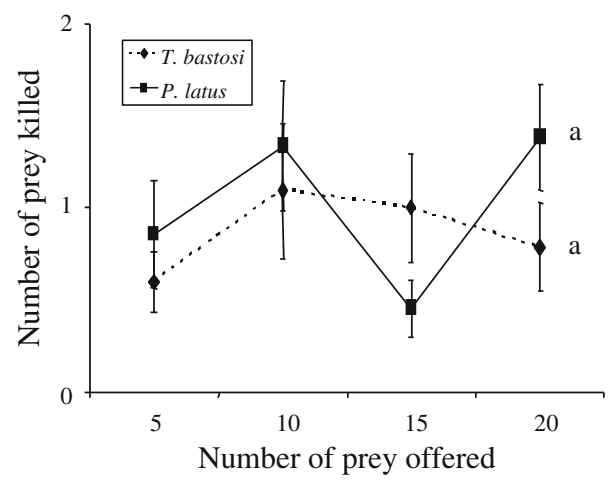

Table 2 Analysis of deviance for the best fitted model with 3 sources of variation (2 categorical: predator species and prey species plus one continuum variable: prey density)

$d f$ Degrees of freedom, Dev deviance, $P$ probability $\chi^{2}$ test

\begin{tabular}{llrl}
\hline Source of variation & $d f$ & Dev. & $P$ \\
\hline Predator & 1 & 104.49 & $1.58 \times 10^{-24}$ \\
Prey & 1 & 14.74 & $1.23 \times 10^{-4}$ \\
Density & 1 & 20.25 & $6.78 \times 10^{-6}$ \\
Predator $\times$ Prey & 1 & 1.02 & 0.31 \\
Predator $\times$ Density & 1 & 2.18 & 0.14 \\
Prey $\times$ Density & 1 & 0.04 & 0.84 \\
Predator $\times$ Prey $\times$ Density & 1 & 0.14 & 0.71 \\
\hline
\end{tabular}

mites in a period of $8 \mathrm{~h}$ (Fig. 1). When fed on T. bastosi, the number of prey killed by I. zuluagai was lower than that obtained by this predator when preying upon P. latus (Fig. 1). Unlike the spider mite $T$. bastosi the broad mite $P$. latus does not produce web making it easier for predation, although several predatory mite species (Acari: Phytoseiidae) have been reported entering dense webbing produced by spider mites (McMurtry and Croft 1997; Lemos et al. 2010). The production of a dense and sticky web on host plants is common in spider mites of the family Tetranychidae (Saito 1979, 1983; Gerson 1985). Although there are large differences in the amount of silk produced and in the structure of the web among tetranychid mite species (Saito 1979, 1983, 1985; Gerson 1985; Morimoto et al. 2006), the general consensus is that such webs have various possible functions, one of which is defense against predators (Gerson 1985; Saito 1985; Lemos et al. 2010). The web can act against predators by repelling them (McMurtry and Johnson 


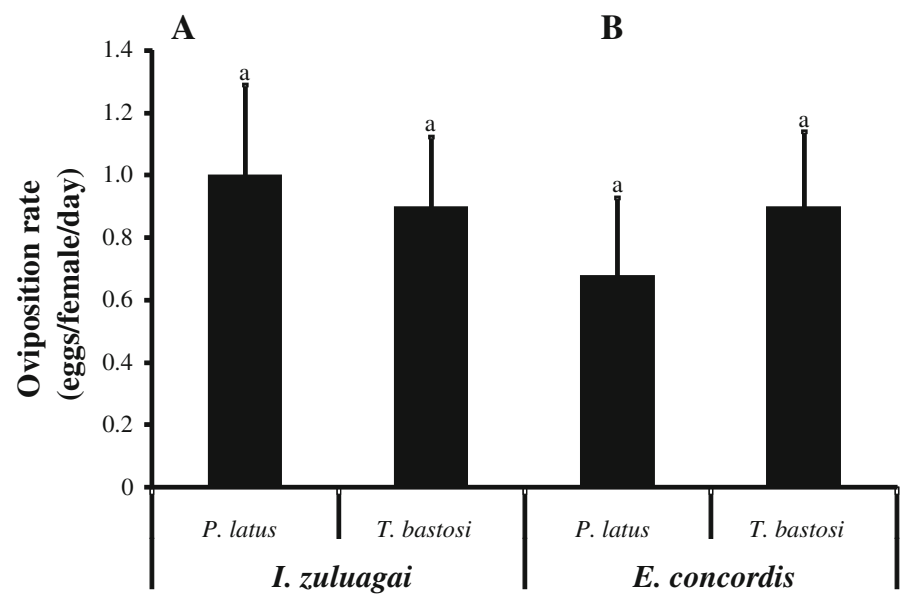

Fig. 3 Average ( \pm SE) ovipositional rate of Iphiseiodes zuluagai (A) and Euseius concordis (B) fed on Polyphagotarsonemus latus and Tetranychus bastosi. Same letters denote non-significant differences among treatments

1966; Takafuji and Chant 1976), by reducing their movement on the plant (Putman 1962; McMurtry et al. 1970; Trichilo and Leigh 1986), or by sticking predators, which may result in their death (McMurtry and Scriven 1964; Trichilo and Leigh 1986; Osakabe 1988; Venzon et al. 2009). Additionally, predators experience difficulty in avoiding contact with the sticky silken threads when they enter and move inside webs (Sabelis and Bakker 1992). This would explain the higher predation rate of I. zuluagai on P. latus compared to $T$. bastosi. Furthermore, the larger size of T. bastosi compared to P. latus, could influencing less predation, thus predators would not need to consume as many individuals of $T$. bastosi as they do on the minute $P$. latus.

At the lowest density, the number of prey consumed by I. zuluagai was lower than two, perhaps due to the difficulty faced by the predator in finding the prey (Reis et al. 2003). Although I. zuluagai and E. concordis preyed upon P. latus and T. bastosi the predation rate of E. concordis was lower for both preys (Tab. 1). The number of P. latus and $T$. bastosi killed by E. concordis peaked around 1 mite in a period of $8 \mathrm{~h}$ (Fig. 2). When fed on $T$. bastosi the daily oviposition of I. zuluagai did not differ from that of $E$. concordis (Fig. 3B). Such ovipositional rates were higher than those obtained by other predatory mites fed on tetranychid mites (Ferla and Moraes 2003) indicating that both P. latus and T. bastosi are suitable for the development of I. zuluagai and E. concordis.

Release-recapture experiments showed that females of I. zuluagai were attracted to odours from leaves of $J$. curcas plants that were infested with P. latus or T. bastosi when offered uninfested leaves as alternative (Fig. 4C, D). These results are in line with previous studies with other predators, indicating that I. zuluagai uses volatile cues to localize their prey habitats (Teodoro et al. 2009). However, more research is needed to determine the nature of the volatiles used by I. zuluagai to perceive the presence of P. latus and T. bastosi on J. curcas leaves. Janssen et al. (1997) showed that the predatory mite Phytoseiulus persimilis Athias-Henriot (Acari: Phytoseiidae) is attracted to odours produced by plants infested with thrips and by plants infested by the two-spotted spider mite Tetranychus urticae. When offered a choice between these two odours, they preferred odours of plants with spider mites. Hence, predators were able to distinguish between plants with either of 

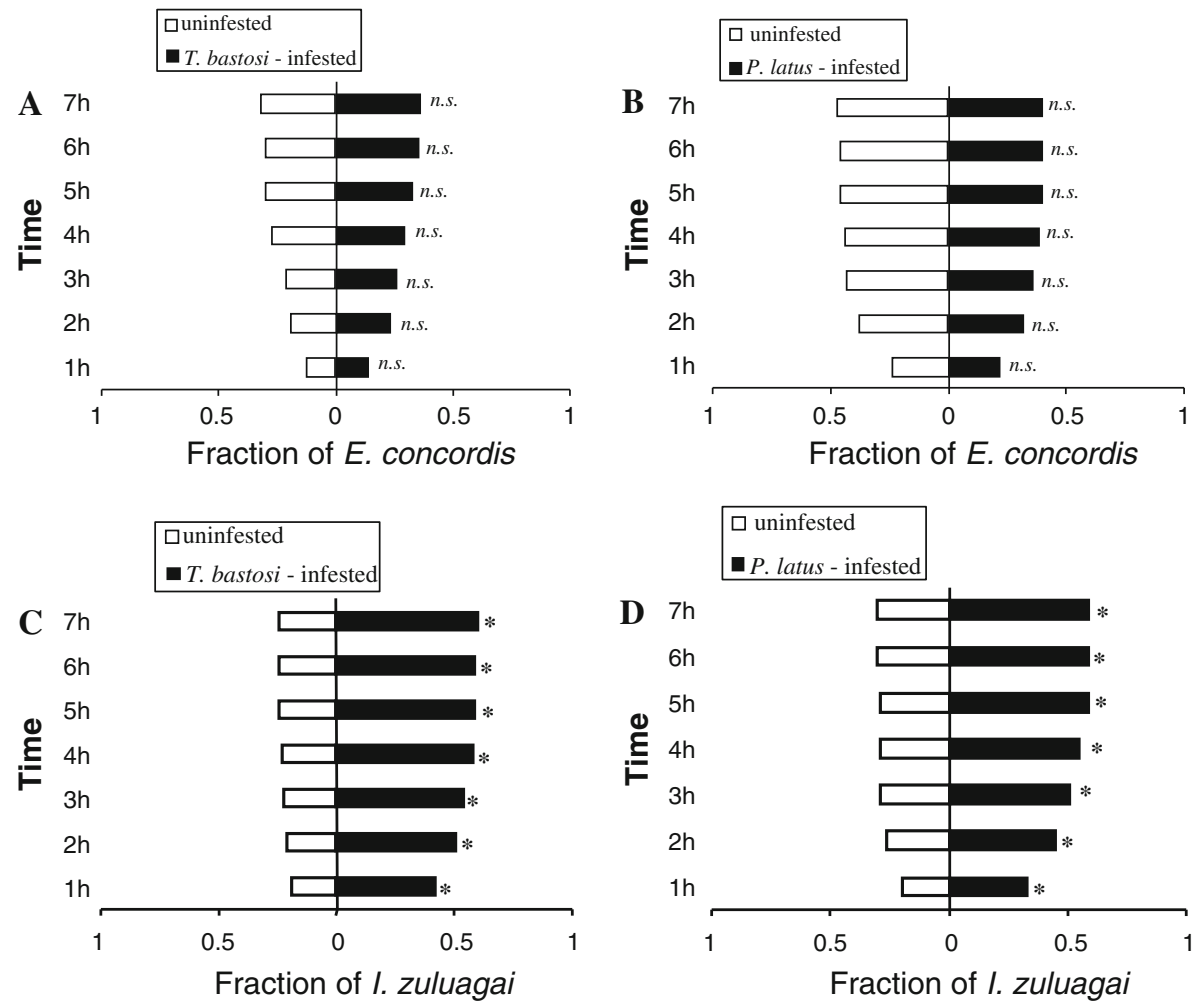

Fig. 4 Phytoseiid predators were offered a choice between uninfested Jatropha curcas leaves and leaves infested with Polyphagotarsonemus latus or Tetranychus bastosi. Preference of Euseius concordis females when offered odours coming from uninfested leaves versus A leaves infested with $T$. bastosi or $\mathbf{B}$ leaves infested with $P$. latus. Preference of Iphiseiodes zuluagai females when offered odours from uninfested leaves versus $\mathbf{C}$ leaves infested with $T$. bastosi or $\mathbf{D}$ leaves infested with $P$. latus. Within each evaluated time, asterisks denote fractions that are statistically different $\left(\chi^{2}\right.$ test; $\left.P<0.05\right)$

the two herbivores. It was argued that this behavior could be explained by different odour profiles being produced by the plant-herbivore complex, by the concentration of similar volatiles, or both. Therefore, it is possible that the presence of spider mites on the leaves of $J$. curcas and their feeding could have elicited the production of volatiles and I. zuluagai may have used such volatiles to locate leaves hosting its prey. When we assessed the preference of E. concordis to leaves of plants infested with P. latus or T. bastosi relative to uninfested leaves, mites did not show preference for one of the odour sources, which suggests that such odours are not attractive to or not recognizable by this predatory mite (Fig. 4A, B).

The preference of I. zuluagai for leaves of plants infested by either P. latus or T. bastosi combined with higher predation on $P$. latus in comparison to that values obtained by E. concordis suggests that I. zuluagai can be more efficient than E. concordis in reducing populations of pest mites under field conditions. Our results emphasize the key importance of predatory mites as agents of natural biological control of pest mites on J. curcas crops. However, more field realistic experiments are needed to elucidate tritrophic relationships among I. zuluagai, E. concordis, their prey, and the host plant. 
Acknowledgments We thank Renata Vieira Marques and Leonardo Teixeira da Silva for support and assistance with the experiments, and two anonymous reviewers for valuable comments on the manuscript. This research was supported by CNPq-Brazil (project 475408/2008-0). DMR and FL received a master scholarship from CNPq-Brazil (projects 561567/2008-5 and 131449/2009-5 respectively). WTK received scientific initiation scholarship from CNPq-Brazil (project 112262/2008-2). AVT was supported by CAPESPNPD, Brasília, Brazil.

Open Access This article is distributed under the terms of the Creative Commons Attribution Noncommercial License which permits any noncommercial use, distribution, and reproduction in any medium, provided the original author(s) and source are credited.

\section{References}

Bolland HR, Gutierrez J, Flechtmann CHW (1998) World catalogue of the spider mite family (Acari: Tetranychidae). Brill, Leiden

Crawley MJ (2007) The R book. Wiley, West Sussex

de Moraes GJ, Delalibera I (1992) Specificity of a strain of Neozygites sp. (Zygomycetes: Entomophthorales) to Mononychellus tanajoa (Acari: Tetranychidae). Exp Appl Acarol 14:89-94. doi:10.1007/ BF01219101

De Moraes GJ, Flechtmann CHW (2008) Manual de Acarologia: acarologia básica e ácaros de plantas cultivadas no Brasil. Holos, Ribeirão Preto, Brazil

De Moraes GJ, McMurtry JA, Denmark HA, Campos CB (2004) A revised catalog of the mite family Phytoseiidae. Zootaxa 1-494

Dicke M (1994) Local and systemic production of volatile herbivore-induced terpenoids: their role in plantcarnivore mutualism. J Plant Physiol 143:465-472

Dicke M, Sabelis MW (1988) Infochemical terminology: based on cost-benefit analysis rather than origin of compounds? Funct Ecol 2:131-139. doi:10.2307/2389687

Fairless D (2007) Biofuel: the little shrub that could - maybe. Nature 449:652-655. doi:10.1038/449652a

Ferla NJ, Moraes GJ (2003) Oviposição dos ácaros predadores Agistemus floridanus Gonzalez, Euseius concordis (Chant) e Neoseiulus anonymus (Chant \& Baker) (Acari) em resposta a diferentes tipos de alimento. Rev Bras Zool 20:153-155. doi:10.1590/S0101-81752003000100019

Gerson U (1985) Webbing. In: Helle W, Sabelis MW (eds) Spider mites: their biology, natural enemies and control. Elsevier, Amsterdam, pp 223-232

Gerson U (1992) Biology and control of the broad mite, Polyphagotarsonemus latus (Banks) (Acari: Tarsonemidae). Exp Appl Acarol 13:163-178. doi:10.1007/BF01194934

Gubitz GM, Mittelbach M, Trabi M (1999) Exploitation of the tropical oil seed plant Jatropha curcas L. Bioresour Technol 67:73-82. doi:10.1016/S0960-8524(99)00069-3

Janssen A, Bruin J, Jacobs G, Schraag R, Sabelis MW (1997) Predators use volatiles to avoid prey patches with conspecifics. J Animal Ecol 66:223-232

Janssen A, Pallini A, Venzon M, Sabelis MW (1999) Absence of odour-mediated avoidance of heterospecific competitors by the predatory mite Phytoseiulus persimilis. Entomol Exp Appl 92:73-82. doi: 10.1023/A:1003708512701

Kavitha J, Ramaraju K, Baskaran V, Pretheep KP (2007) Bioecology and management of spider mites and broad mites occurring on Jatropha curcas L. in Tamil Nadu, India. Syst Appl Acarol 12:109-115

Kuhn M, Weston S, Wing J, Forester J (2008) The contrast package. http://cran.nedmirror.nl/web/packages/ contrast/vignettes. Accessed 07 October 2009

Kumar A, Sharma S (2008) An evaluation of multipurpose oil seed crop for industrial uses (Jatropha curcas L.): a review. Ind Crop Prod 28:1-10. doi:10.1016/j.indcrop.2008.01.001

Lemos F, Sarmento RA, Pallini A, Dias CR, Sabelis MW, Janssen A (2010) Spider mite web mediates antipredator behaviour. Exp Appl Acarol. doi: 10.1007/s10493-010-9344-1

Lopes EN (2009) Bioecologia de Polyphagotarsonemus latus em acessos de pinhão manso (Jatropha curcas). Dissertation, Federal University of Viçosa

McMurtry JA, Croft BA (1997) Life-styles of phytoseiid mites and their roles in biological control. Annu Rev Entomol 42:291-321. doi:10.1146/annurev.ento.42.1.291

McMurtry JA, Johnson HG (1966) An ecological study of the spider mite Oligonychus punicae (Hirst) and its natural enemies. Hilgardia 37:363-402

McMurtry JA, Scriven GT (1964) Studies on the feeding, reproduction, and development of Amblyseius hibisci (Acarina: Phytoseiidae) on various food substances. Ann Entomol Soc Am 57:649-655 
McMurtry JA, Huffaker CB, Van de Vrie M (1970) Ecology of tetranychid mites and their natural enemies: a review. I. Tetranychid enemies: their biological characters and the impact of spray practices. Hilgardia 40:331-390

Morimoto K, Furuichi H, Yano S, Osakabe MH (2006) Web-mediated interspecific competition among spider mites. J Econ Entomol 99:678-684. doi:10.1603/0022-0493(2006)99[678:WICASM]2.0.CO;2

Nature Editorial (2007) Kill king corn. Nature 449:637. doi:10.1038/449637a

Oliveira H, Janssen A, Pallini A, Venzon M, Fadini M, Duarte V (2007) A phytoseiid predator from the tropics as potential biological control agent for the spider mite Tetranychus urticae Koch (Acari: Tetranychidae). Biol Control 42:105-109. doi:10.1016/j.biocontrol.2007.04.011

Oliveira H, Fadini M, Venzon M, Rezende D, Rezende F, Pallini A (2009) Evaluation of the predatory mite Phytoseiulus macropilis (Acari: Phytoseiidae) as a biological control agent of the two-spotted spider mite on strawberry plants under greenhouse conditions. Exp Appl Acarol 47:275-283. doi:10.1007/ s10493-008-9217-z

Openshaw K (2000) A review of Jatropha curcas: an oil plant of unfulfilled promise. Biomass Bioenergy 19:1-15. doi:10.1016/S0961-9534(00)00019-2

Osakabe M (1988) Relationships between food substances and developmental success in Amblyseius sojaensis Ehara (Acarina : Phytoseiidae). Appl Entomol Zool 23:45-51

Pallini A, Janssen A, Sabelis MW (1997) Odour-mediated responses of phytophagous mites to conspecific and heterospecific competitors. Oecologia 110:179-185. doi:10.1007/s004420050147

Peña JE, Bullock RC (1994) Effects of feeding of broad mite (Acari: Tarsonemidae) on vegetative plant growth. Fla Entomol 77:180-184

Putman W (1962) Life-history and behaviour of the predacious mite Typhlodromus (T.) caudiglans Schuster (Acarina: Phytoseiidae) in Ontario, with notes on the prey of related species. Can Entomol 94:163-177

R Development Core Team (2006) R foundation for statistical computing. Vienna, Austria

Reis PR, Alves EB (1997) Criação do ácaro predador Iphiseiodes zuluagai Denmark \& Muma (Acari: Phytoseiidae) em laboratório. An Soc Entomol Bras 26:565-568. doi:10.1590/S0301-80591997000 300021

Reis PR, Sousa EO, Teodoro AV, Pedro Neto M (2003) Effect of prey density on the functional and numerical responses of two species of predaceous mites (Acari: Phytoseiidae). Neotrop Entomol 32:461-467. doi:10.1590/S1519-566X2003000300013

Rosa AA, Gondim Jr MGC, Fiaboe KKM, Demoraes GJ, Knapp M (2005) Predatory mites associated with Tetranychus evansi Baker \& Pritchard (Acari: Tetranychidae) on native solanaceous plants of coastal Pernambuco State, Brazil. Neotrop Entomol 34:689-692. doi:10.1590/S1519-566X2005000400021

Sabelis MW, Bakker FM (1992) How predatory mites cope with the web of their tetranychid prey: a functional view on dorsal chaetotaxy in the Phytoseiidae. Exp Appl Acarol 16:203-225. doi: 10.1007/BF01193804

Sabelis MW, Janssen A, Kant MR (2001) Ecology—the enemy of my enemy is my ally. Science 291:2104-2105. doi:10.1126/science.1059939

Saito Y (1979) Study on spinning behaviour of spider mites. III. Responses of mites to webbing residues and their preferences for particular physical conditions of leaf surfaces (Acarina: Tetranychidae). Jap J Appl Entomol Zool 23:82-91

Saito Y (1983) The concept of "life types" in Tetranychinae. An attempt to classify the spinning behaviour of Tetranychinae. Acarologia 24:377-392

Saito Y (1985) Life types of spider mites. In: Helle W, Sabelis MW (eds) Spider mites: their biology, natural enemies and control. Elsevier, Amsterdam, pp 253-264

Santos HO, Silva-Mann R, Poderoso JCM, Oliveira AS, Carvalho SVA, Boari AJ, Ribeiro GT, Navia D (2006) O ácaro Tetranychus bastosi Tuttle, Baker \& Sales (Prostigmata: Tetranychidae) infestando germoplasma nativo de Jatropha sp., no estado de Sergipe, Brasil: $2^{\circ}$ Congresso Brasileiro de Mamona

Takafuji A, Chant D (1976) Comparative studies of two species of predacious phytoseiid mites (Acarina: Phytoseiidae), with special reference to their responses to the density of their prey. Res Popul Ecol 17:255-310. doi:10.1007/BF02530777

Teodoro A, Pallini A, Oliveira C (2009) Sub-lethal effects of fenbutatin oxide on prey location by the predatory mite Iphiseiodes zuluagai (Acari: Phytoseiidae). Exp Appl Acarol 47:293-299. doi: 10.1007/s10493-008-9219-x

Trichilo PJ, Leigh TF (1986) Predation on spider mite eggs by the western flower thrips, Frankliniella occidentalis (Thysanoptera: Thripidae), an opportunist in a cotton agroecosystem. Environ Entomol $15: 821-825$

Turlings TCJ, Tumlinson JH, Lewis WJ (1990) Exploitation of herbivore-induced plant odors by hostseeking parasitic wasps. Science 250:1251-1253. doi:10.1126/science.250.4985.1251 
Tuttle DM, Baker EW, Sales FM (1977) Spider mites (tetranychidae: acarina) of the state of Ceara, brazil. Int J Acarol 3:1-8

Venzon M, Lemos F, Sarmento RA, Rosado MC, Pallini A (2009) Predação por coccinelídeos e crisopídeo influenciada pela teia de Tetranychus evansi. Pesqu Agropecu Bras 44:1086-1091. doi:10.1590/ S0100-204X2009000900003 